\title{
ECHINOSPARTUM ALGIBICUM (LEGUMINOSAE) REGENERACIÓN DE PLANTAS MEDIANTE ORGANOGÉNESIS ADVENTICIA
}

\author{
Rafael ZÁRATE, Abelardo APARICIO, Manuel CANTOS y Antonio TRONCOSO
}

\begin{abstract}
RESUMEN. Echinospartum algibicum (Leguminosae) regeneración de plantas mediante organogénesis adventicia. La germinación in vitro de semillas de E. algibicum, especie endémica de la Sierra de Grazalema, S de España, así como la inducción de yemas múltiples y el desarrollo posterior de brotes, se consiguió en el medio de cultivo de Murashige y Skoog a mitad de concentración, con 3\% de sacarosa y citoquinina (BAP) a las concentraciones de 1 y $2 \mathrm{mg} \mathrm{l}^{-1}$ (ECH-1, ECH-2). La germinación de las semillas se incrementó significativamente de $38 \%$ a casi $100 \%$ tras la escarificación. El número medio de yemas formado después de 35-40 días fue de 8,6 y 6,9 en los medios ECH-1 y ECH-2 respectivamente. Los brotes fueron posteriormente enraizados en el mismo medio nutritivo pero sustituyendo la citoquinina por la auxina IBA $\left(0.2 \mathrm{mg} \mathrm{l}^{-1}\right)$. En este medio, se consiguió un porcentaje medio de enraizamiento de 35,49 después de 25-30 días, y en algunos casos la formación de masas de callo en las zonas de los brotes en contacto con el medio nutritivo. Finalmente, se ensayó la aclimatación de estas plantas a suelo mediante reducción progresiva de la humedad relativa y tras varios tratamientos que incluyeron el uso de $\mathrm{CO}_{2}$, la adición de inoculo de micorriza (Glomus deserticola) al substrato de cultivo, así como el uso de un medio de cultivo sin reguladores de crecimiento y mitad de sacarosa previo paso a suelo. Los porcentajes de supervivencia después de 60 días en suelo fueron mayores para la plantas sometidas a los tratamientos con $\mathrm{CO}_{2}$ aunque los porcentajes medios fueron algo bajos.
\end{abstract}

Palabras clave. Conservación, Echinospartum, germinación de semillas, micorrizas.

ABSTRACT. Echinospartum algibicum (Leguminosae), plant regeneration via adventitious organogenesis. In vitro seed germination of E. algibicum, an endangered species, multiple bud induction and shoot growth was achieved on a growth medium composed of half strength Murashige and Skoog medium, with 3\% sucrose and BAP at 1 and $2 \mathrm{mg} \mathrm{l}^{-1}$ (ECH-1, ECH-2). Seed germination increased significantly after scarification (from 38\% to almost 100\%). The mean number of buds formed after 35-40 days was 8.6 and 6.9 on ECH-1 and ECH-2 media respectively. Shoots were then rooted on the same medium but substituting the cytokinin by the auxin IBA $\left(0.2 \mathrm{mg} \mathrm{l}^{-1}\right)$. On this medium the mean maximum rooting percentage was 35.49 after 25-30 days; in some cases, callus formation took place on the shoot areas in contact with the nutrient medium. Finally, acclimatization of rooted shoots was achieved through progressive reduction of relative humidity and after several treatments including use of $\mathrm{CO}_{2}$, addition of mycorrhizal fungus (Glomus deserticola) inocula to the substrate, as well as the use of a nutrient medium lacking any plant growth regulators with half the amount of sucrose, prior transferring to soil. After 60 days in soil, survival rates were higher for plants treated with $\mathrm{CO}_{2}$, although the mean survival percentages were rather low.

Key words. Conservation, Echinospartum, seed germination, mycorrhiza.

Esta investigación ha sido financiada por la CICYT proyecío número AMB94-1372. 


\section{INTRODUCCIÓN}

El género Echinospartum, endémico del sur de Francia y. la Península Ibérica, se compone de cinco especies silicícolas y calcícolas, que se localizan habitualmente en zonas montañosas por encima de 1000 m.s.m. (Rivas Martínez, 1974). Equinospartum algibicum ha sido recientemente descrita (Talavera y Aparicio, 1995), y la única población que se conoce de esta especie se localiza en suelos silíceos de la unidad del Aljibe en el Parque Natural Sierra de Grazalema (Andalucía, España) entre 800-830 m.s.m.; esta especie se encuentra actualmente en peligro de extinción debido fundamentalmente a la presión del ganado caprino que somete las plantas a un intenso ramoneo. La población está integrada por unos pocos individuos (80-90) de los que tan solo 3 llegan a florecer y fructificar (Aparicio y Guisande, 1995). Aunque no se conoce bien la ecología, biología y sistema de reproducción de esta especie, existen estudios acerca de la germinación de semillas y supervivencia de plántulas para evaluar las posibilidades de regenerar esta especie a partir del banco permanente de semillas que existe en el suelo (Aparicio, 1993; Aparicio y Guisande, 1997).

En la actualidad, se presta gran atención a la aplicación del cultivo in vitro para conservar especies valiosas o en peligro de extinción (Bramwell, 1990; Fay, 1992, Arregui et al. 1993 y sus citas; Zárate et al. 1997). La situación tan crítica en que se encuentra $E$. algibicum nos ha hecho ensayar su propagación mediante técnicas de cultivo in vitro (Yeoman, 1986). Mediante el uso de estas técnicas se han obtenido resultados interesantes en diversos taxones de plantas amenazadas, residiendo una parte importante del éxito en la puesta a punto de las técnicas, especialmente en grupos de plantas con los que no se ha trabajado previamente (Bramwell, 1990, Clemente et al. 1991).
El objetivo de este trabajo es establecer un protocolo de micropropagación de $E$. algibicum con especial referencia a las distintas fases del proceso de propagación: (a) esterilización y establecimiento del cultivo, (b) multiplicación de yemas, (c) aislamiento de las yemas-brotes producidos para su desarrollo y posterior enraizamiento y $(d)$ aclimatación de las plantas ya enraizadas a condiciones de suelo. El fín último es conseguir la aclimatación de plantas y su introducción en el Jardín Botánico del Parque de Grazalema como parte de un proyecto más amplio acerca del conocimiento y conservación de esta especie.

\section{MATERIALES Y MÉTODOS}

\section{a) Germinación de semillas y desarrollo de yemas adventicias}

Las semillas, fácilmente reconocibles, fueron recolectadas en septiembre de 1995 bajo una de las plantas que florece, una vez finalizada la dispersión. La esterilización se realizó mediante inmersión en etanol $80 \%$ durante 30 segundos, seguida de $25 \mathrm{~min}$. en agitación en una solución acuosa al $21 \%$ de $\mathrm{NaOCl}$ tomada de una solución de lejía comercial. Finalmente las semillas fueron lavadas tres veces con agua destilada esterilizada.

Antes de proceder a la inoculación de las semillas en medio de cultivo, éstas se escarificaron practicando con un bisturí un corte superficial $(2-3 \mathrm{~mm}$.) a la testa en la parte opuesta a la ocupada por la radícula del embrión. Las semillas escarificadas $(n=96)$ fueron cultivadas en tubos de ensayo $(150 \times 25 \mathrm{~mm})$ conteniendo un medio nutritivo estéril que incluía los elementos minerales y vitaminas del medio de Murashige y Skoog (1962) a mitad de concentración (1/2MS), conteniendo $3 \%$ sacarosa, y $1 \mathrm{mg} \mathrm{l}^{-1}$ BAP (bencilaminopurina) (ECH-1) o bien $2 \mathrm{mg} \mathrm{l}^{-1}$ 
BAP (ECH-2), solidificados con 0,5\% agar y $\mathrm{pH}=5,7$. Por su parte las semillas no escarificadas $(n=48)$ se cultivaron en el medio ECH-1. En estos medios, además de la germinación de las semillas se consiguió la inducción y multiplicación de yemas adventicias con el posterior desarrollo de brotes.

\section{b) Enraizamiento}

Para el enraizamiento de los brotes aislados se utilizó el mismo medio nutritivo pero sustituyendo la citoquinina (BAP) por auxina (AIB) a una concentración de $0.2 \mathrm{mg}$ $\mathrm{I}^{-1}$ (medio R/3). Los brotes producidos en los medios ECH-1 y ECH-2 (aprox. 600) fueron aislados y transferidos asépticamente a este medio manteniéndose en el mismo durante aproximadamente 30-35 días.

Una vez conseguida la inducción de raíces, 40 plántulas fueron transferidas al medio $1 / 2$ MS conteniendo $1,5 \%$ de sacarosa (mitad de la concentración usada comúnmente), carente de reguladores de crecimiento, cultivándose en este medio por 35-40 días previo paso a suelo. Las demás plantas enraizadas se transfirieron posteriormente a suelo.

Los cultivos se incubaron a $25 \pm 2{ }^{\circ} \mathrm{C}$ y fotoperíodo de 16:8 h (luz/oscuridad). La iluminación se consiguió con tubos fluorescentes (Cool White) que proporcionaron una radiación de $30 \mu \mathrm{mol} \mathrm{m} \mathrm{m}^{-2} \mathrm{~s}^{-1}$.

\section{c) Aclimatación a condiciones de suelo y tratamiento con micorrizas}

Un grupo de plantas enraizadas $(n=94)$, tanto en el medio conteniendo auxinas (R/3), como provenientes del medio (1/2 MS; $1,5 \%$ sacarosa) posterior al tratamiento auxínico, se colocaron, tras eliminar el agar de sus raíces en contenedores plásticos $(330 \mathrm{ml})$ conteniendo suelo arenoso de la localidad original en el Parque, al que se le añadió en ciertos casos $(n=80)$ turba comercial en la proporción $2: 1$ (suelo-turba).
Otro grupo de plantas enraizadas en el medio $R / 3(n=50)$ se sometieron en tubos de ensayo a tratamientos con $\mathrm{CO}_{2}$ para estimular la fotosíntesis y su madurez metabólica foliar previo paso a suelo. La producción de $\mathrm{CO}_{2}$ se consiguió mezclando 0,5-1,0 gr de carbonato cálcico con 1-2 ml de una solución de $\mathrm{HCl} 1 \mathrm{~N}$. Los tubos de ensayo, sin tapas, conteniendo las plantas enraizadas se colocaron en un recipiente cubierto con una bolsa plástica para así mantener la atmósfera de $\mathrm{CO}_{2}$ producida, repitiéndose esta práctica tres veces en tres días consecutivos.

Por otro lado, para estudiar el posible efecto de la micorrización en la supervivencia de las plantas micropropagadas $(n=72)$, al substrato arriba descrito se le aplicó, en el momento de la colocación en vaso, una cucharada de inoculo conteniendo la micorriza (Glomus deserticola), arena, además de restos de raíces de avena.

Posteriormente, los vasos con el substrato y las plantas se cubrieron con bolsas de plástico transparentes para mantener una atmósfera húmeda, colocándose luego en el invernadero. Después de 3-4 días se practicó un corte en una de las esquinas de la bolsa para permitir el contacto con el medio atmosférico, y así reducir paulatinamente la alta humedad. El segundo corte a la otra esquina se realizó a los 6-7 días, y a los 9-10 días se procedió a la eliminación de la bolsa, quedando las plantas directamente en contacto con el medio ambiente.

Para determinar la existencia de micorrizas tras 18 días en suelo, se tomaron muestras de raíces de plantas cultivadas en substrato con y sin la adición de micorrizas. Debido al efecto destructivo de la toma de raíces, ésta se practicó sólo con dos individuos de cada tratamiento.

El método seguido fue una variación del descrito por Phillips y Hayman (1970). Las raíces fueron lavadas con agua del grifo y posteriormente sumergidas en una solución al $10 \%$ de $\mathrm{KOH}$ calentada a $121^{\circ} \mathrm{C}$ y presión de 
0,1 $\mathrm{MPa}$. durante $15 \mathrm{~min}$. Tras ser enjuagadas tres veces con agua destilada y una final con $0.1 \mathrm{~N} \mathrm{HCl}$, las raíces fueron teñidas con $0,05 \%$ $(\mathrm{p} / \mathrm{v})$ azul de tripán en lactoglicerol durante 10 min. Seguidamente, éstas se sumergieron en una solución acuosa al 50\% de EtOH hasta que fueron montadas en un porta y observadas bajo un microscopio óptico.

\section{RESULTADOS}

\section{a) Germinación de semillas, inducción y desarrollo de yemas adventicias}

Los resultados presentados en la figura 1 muestran los porcentajes de germinación de las semillas de E. algibicum en diferentes medios de cultivo y también en relación a la escarificación o no de las mismas. Se observa que la germinación fue significativamente mayor para las semillas que habían sido escarificadas (ca. 100\%), observándose además que la citoquinina presente en los medios de cultivo utilizados (ECH-1 y ECH-2) no influyó en la germinación ya que se consiguieron porcentajes estadísticamente similares en ambos medios (análisis Chi-cuadrado).

La inducción de yemas adventicias ocurrió 8-12 días después de la germinación, cuando las plántulas producidas habían emitido los cotiledones y la primera hoja vegetativa. Esta inducción se observó tanto en la superficie de los cotiledones, como en los epicotilos y en la yema apical originariamente producida. Tras 45 días de cultivo en los medios ECH-1 y ECH2 se produjo un número medio de yemas desarrolladas por plántula de 8,5 y 6,9 respectivamente, aunque no existió diferencia significativa. No obstante, el número de plántulas que indujeron yemas axilares fue estadísticamente mayor en el medio ECH-1 que ECḦ-2 (tab. 1). Además el desarrollo de callos y en algunos casos vitrificación, fueron más intensos en las plántulas germinadas y crecidas en el medio ECH-2.

\section{b) Enraizamiento de brotes}

El enraizamiento de los brotes aislados de E. algibicum, originados en los medios ECH-1 y ECH-2, se consiguió en el medio R/3. La emisión de las primeras raíces se observó para algunos brotes después de 10-12 días en este medio, aunque la emisión fue manifiestamente más clara después de 25-30 días, alcanzándose entonces porcentajes medios de enraizamiento de $35,49 \%$, independientemente del medio inicial en el que se originaron los brotes. También en algunos casos se observó en la base de los brotes en contacto con este medio nutritivo la aparición de callo.
Medios de cultivo Porcentaje de plántulas en donde se indujeron yemas adventicias $(n=96)$
Número medio de yemas adventicias por plántula $(\mathrm{n}=96)$
$\mathrm{ECH}-1$
$71,15^{\mathrm{A}}$
$8,6 \pm 1,65^{\mathrm{a}}$
$\mathrm{ECH}-2$
$42,16^{\mathrm{B}}$
$6,9 \pm 2,14$

Tabla 1. Inducción de yemas adventicias en plántulas de Echinospartum algibicum en diferentes medios de cultivo después de 35-40 días desde el inicio del experimento. El número de plantas por tratamiento se indica entre paréntesis. Análisis estadístico $\chi^{2}=7,417$, grado sign. 6,45x 10-3 (Indices en letra mayúscula) y test de Tuckey F prob. 0,5579 (Indices en letras minúsculas). Adventitious bud induction on Echinospartum algibicum plantlets cultured on different nutrient media after 35-40 days from the initiation of the experiment. The number of plants per treatment is indicated in brackets. Statistical analysis $\chi^{2}=7,417$, sign. level 6,45x10-3 (upper case) and Tuckyey's test F prob. 0,5579 (lower case). 


\section{c) Aclimatación y micorrizas}

Los resultados de la aclimatación de $E$. algibicum a suelo después de 60 días se muestran en la tabla 2. Se observa que las plantas transferidas directamente del medio R/ 3 a suelo muestran los porcentajes más bajos de supervivencia, $10,0 \%$ y $6,40 \%$, para suelo con y sin micorriza respectivamente y no presentaron diferencia estadística $\left(\chi^{2} 0,79\right.$, nivel sign. 0,374). El porcentaje de supervivencia de las plantas provenientes del medio $1 / 2 \mathrm{MS}, 1,5 \%$ sacarosa, fue similar para las que contenían la preparación micorrízica $(23,8 \%)$ en relación a los controles $(18,0 \%)\left(\chi^{2}\right.$ 0,804 , nivel sign. 0,369). En cuanto a las plantas que fueron sometidas a los tratamientos con $\mathrm{CO}_{2}$, estas muestran unos porcentajes de supervivencia estadísticamente diferentes con respecto a los otros dos tratamientos $(\mathrm{R} / 3$ y $1 /$ $2 \mathrm{MS} 1,5 \%$ sacarosa) ( $\chi^{2} 24,89$, nivel sign. $6,04 \times 10^{-7}$ y c2 4,704 , nivel sign. 0,030) (tab. 2). Por otro lado, no se presentó diferencia estadística en las plantas tratadas con $\mathrm{CO}_{2}$, que fueron cultivadas en suelo y micorrizas con o sin turba $\left(\chi^{2}\right.$ 0,502, nivel sign. 0,478).

La tinción con azul de tripán mostró la presencia de hifas y vesículas teñidas de color azul en las raíces de E. algibicum. Esta infección ocurrió en las raíces de plantas cultivadas en los distintos substratos a los que se le añadió micorrizas (suelotturba+ micorriza; suelo+micorriza), incluso en las raíces de plantas cultivadas en substrato sin micorriza (suelo+turba), indicando que la turba y/o el suelo empleados también parecen poseer micorrizas infectivas. No obstante, es necesario mencionar que aquellas raíces de plantas de $E$. algibicum procedentes de substratos a los que se les añadió el inoculo de micorrizas, presentaron un mayor número de hifas y vesículas micorríticas. Sin embargo, los datos de la supervivencia comparables para estos substratos con y sin micorrizas (medios R/3 y 1/2MS $1,5 \%$ sacarosa) (tab. 2) no mostraron diferencias estadísticamente significativas, aunque este porcentaje fue mayor en los substratos a los que se les añadió micorrizas.

\section{DISCUSIÓN}

La escarificación de las semillas supuso un incremento en la tasa de germinación desde aproximadamente $38 \%$ hasta casi $100 \%$, lo que parece señalar que la testa ejerce un claro efecto mecánico inhibidor en la germinación.

Tratamiento

Porcentaje de supervivencia

Tipos de suelo

Suelo+Turba+Micorriza Suelo+Micorriza Suelo+Turba

\begin{tabular}{|c|c|c|c|}
\hline $\mathrm{R} / 3$ & $10,00 \%(10)^{\mathrm{aA}}$ & & $6,40 \%(10)^{\mathrm{aA}}$ \\
\hline $1 / 2$ MS, $1,5 \%$ sacarosa & $23,80 \%(12)^{\mathrm{hA}}$ & - & $18,00 \%(12)^{\mathrm{hA}}$ \\
\hline $\mathrm{R} / 3+\mathrm{CO}_{2}$ & $41,30 \%(36)^{\mathrm{cA}}$ & $48,00(14)^{\mathrm{A}}$ & - \\
\hline
\end{tabular}

Tabla 2. Porcentajes de supervivencia de plantas de Echinospartum algibicum tras su aclimatación a suelo después de 60 días. El número de plantas por tratamiento se indica entre paréntesis. Los valores entre columnas o filas no seguidos de la misma letra (mayúsculas columnas, minúsculas filas) difieren significativamente mediante el test de $\chi^{2}$ (grado lib. 1). Survival percentage of Echinospartum algibicum plants following aclimatization to soil after 60 days. The number of plants per treatment is indicated in brackets. Values within a column or a row not followed by the same letter (upper case columns, lower case rows) differ significantly by $\chi^{2}$ test analysis (d.f. 1). 


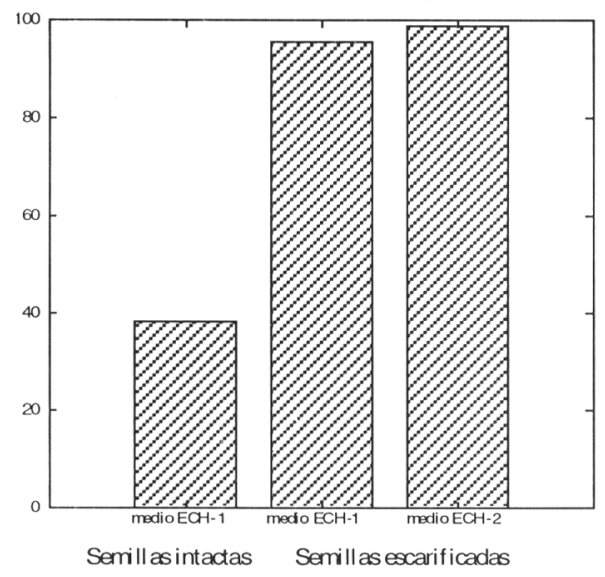

Figura 1. Porcentaje de germinación de semillas de Echinospartum algibicum en diferentes medios de cultivo tras ser o no escarificadas $\left(\chi^{2}=24,34\right.$; grado sign. $8,03 \times 10-7$ y $\chi^{2}=26,62$; grado sign. $2,47 \times 10^{-7}$ ). Germination percentage of Echinospartum algibicum seeds on different growth media before and after scarification $\left(\chi^{2}=24,34\right.$; sign. level $8,03 \times 10-7$ and $\chi^{2}=26,62 ;$ sign. level 2,47x10-7).

Este resultado confirma los obtenidos por Aparicio (1993) y Aparicio y Guisande (1997), en los que un efecto mecánico inhibidor de la testa de semillas de E. algibicum fue también señalado, al igual que sucede en muchas otras leguminosas.

La germinación de semillas escarificadas en medio carente de citoquinina también tuvo lugar originando porcentajes similares (datos no mostrados), lo que indica que la presencia de BAP no afecta a la germinación. No obstante, la transferencia posterior de estas plántulas a los medios conteniendo citoquinina para la multiplicación de yemas (ECH-1 y ECH-2), no provocó ninguna respuesta. Este resultado confirma el publicado por Hussey (1986), donde se indica la importancia del tiempo de la toma de explantos en un momento apropiado de su estadío de desarrollo para conseguir respuesta. Aquí se observa que las plántulas de $E$. algibicum son sensibles y responden al tratamiento con citoquinina (BAP), si éste se utiliza como medio de germinación pero no responden al tratamiento si la BAP se aplica una vez desarrolladas las plantulas en medio nutritivo base.

A pesar de que el porcentaje medio de enraizamiento de brotes fue relativamente bajo, el medio $R / 3$ fue el que produjo mejores resultados $(35,49 \%)$. El incremento en la cantidad de AIB (>0,2 $\mathrm{mg} \mathrm{l}^{-1}$ ) produjo peores resultados; de la misma manera el uso de la auxina ANA provocó una mayor formación de callos que pareció inhibir el enraizamiento (datos no mostrados). También se empleó tiamina $\left(0,8 \mathrm{~g} \mathrm{l}^{-1}\right)$ en el medio de enraizamiento, observándose un pobre desarrollo de las partes aéreas (dato no mostrado), resultado opuesto a Chee (1995) quien indicó que la tiamina provocaba la estimulación del enraizamiento y posterior desarrollo de plantas, también leñosas, del género Taxus.

La aclimatación de plantas a suelo es e] estadío final en los protocolos de micropropagación, y éste es especialmente delicado en plantas leñosas. Diversos autores (Scott, 1986; Pennell, 1987) han indicado la transcendencia que tratamientos preliminares, como por ejemplo la composición del medio de cultivo o el medio ambiente que rodea a las plantas, tienen para la aclimatación de las plantas producidas in vitro.

En este estudio, la baja tasa de supervivencia en la aclimatación registrada con las plantas enraizadas procedentes del medio R/3 puede deberse al exceso de humedad al mantener las bolsas plásticas por un período excesivamente largo, lo que pudo originar una infección fúngica que causó la muerte de muchos de los plantas. El tiempo en el que posteriormente se mantuvieron las plantas en suelo cubiertas con bolsas se redujo ostensiblemente. Este acortamiento de 16-18 días a 8-9 días aumentó claramente la supervivencia de las plantas.

El tratamiento con $\mathrm{CO}_{2}$ incrementó el número de plantas aclimatadas a suelo después de 60 días en los sustratos utilizados (tab. 2). 
El $\mathrm{CO}_{2}$ se aplica para 'despertar' la madurez foliar de las plantas producidas in vitro, pues es conocido que debido a las condiciones de alta humedad y presencia de sacarosa en el medio de cultivo, los mecanismos fotosintético y estomático no funcionan o están mínimamente activos, así como la carencia de ceras y cutícula foliares (Stafford, 1991). Se observó un claro incremento en la supervivencia para las plantas tratadas con $\mathrm{CO}_{2}$ (tab. 2) indicándose la efectividad de este tratamiento para la posterior aclimatación de plantas de E. algibicum a suelo. Sin embargo, los porcentages de supervivencia en algunos casos fueron bajos y parecieron disminuir a su vez con el tiempo de aclimatación. Un resultado similar fue descrito por Aparicio y Guisande (1997), donde plantas de E. algibicum obtenidas tras la germinación tanto de semillas jóvenes como de semillas presuntamente con más de 20 años procedentes del banco de semillas de suelo y cultivadas en suelo tomado de la población natural, no sobrevivieron después de un período de 20 semanas, a pesar de los altos porcentajes de germinación. Estos autores plantearon la posibilidad de que el bajo número de plantas que fructifican en la actualidad pueda causar pérdida de viabilidad y 'fitness' de los embriones producidos. No obstante, las plantas en cultivo no siempre se comportan como en la naturaleza y condiciones subóptimas de cultivo o problemas ecofisiológicos podrían también ser la causa de estos resultados. Sin embargo, los resultados alcanzados animan a la propagación de esta especie amenazada empleando estas técnicas.

El uso de la micorriza $G$. deserticola, no produjo un incremento significativo en la aclimatación (tab. 2). Tras 18 días, las plantas aclimatadas en suelo sin la adición de esta micorriza aparecieron también positivas a la tinción con azul de tripán, por lo que parecen también existir en la turba o en el suelo de la población natural utilizados, ya que positivamente infestaron a las plantas de $E$. algibicum. La mayor infección (mayor número de hifas y vesículas por raíz y planta) de aquellas plantas a las que se le añadió la preparación de micorrizas pudieĩa explicar que en algunos casos el porcentaje de supervivencia fuera mayor, coincidiendo con Tremblay et al. (1986) quienes describieron el uso de simbiosis micorrízica para el paso a suelo de plantas del género Alnus, lo que produjo un incremento en el número de plantas aclimatadas comparado con las no micorrizadas.

En el presente trabajo, el primero que se desarrolla con plantas del género Echinospartum y que probablemente representa uno de los escasos trabajos en Genisteas, se ha iniciado con éxito la puesta a punto para la propagación de la especie, aunque las fases de enraizamiento y, sobre todo, la supervivencia posterior de las plantas, no han arrojado aún los resultados deseables. No obstante, en otras especies amenazadas, como Cistus heterophyllus, esta técnica ha resultado muy exitosa (Arregui et al. 1993), por lo que deben continuar los estudios en esta línea que junto con el conocimiento de la biología, ecología y estructura de la población puedan garantizar el conocimiento de la misma y su total conservación y regeneración.

\section{BIBLIOGRAFÍA}

APARICIO, A. -1993- Planes de Recuperación de especies vegetales amenazadas en el Parque Natural de la sierra de Grazalema (CádizMálaga). Acta Bot. Malacitana 18: 199-221.

APARICIO, A. y R. GUISANDE - 1995- Ecología y conservación de Echinospartum algibicum Talavera \& Aparicio (Genisteae, Fabaceae). Acta Bot. Malacitana 20: 298-301.

APARICIO A. \& R. GUISANDE-1997-Replenishment of the endangered Echinospartum algibicum (Genisteae, Fabaceae) from the soil seed bank. Biological Conservation 79: 267-273.

APARICIO, A. y S. SILVESTRE -1987-Flora del Parque Natural de la Sierra de Grazalema. Agencia de Medio Ambiente, Sevilla. 
ARREGUI, J.M., J. JUAREZ, E. LAGUNA, S. REYNA y L. NAVARRO -1993Micropropagación de Cistus heterophyllus. Un ejemplo de la aplicación del cultivo de tejidos a la conservación de especies amenazadas. Vida Silvestre 74: 24-29.

BRAMWELL, D. -1990- The rôle of in vitro cultivation in the conservation of endangered species. En: J.E. Hernández-Bermudez, M.Clemente y V. Heywood (eds.), Conference on Conservation Techniques in Botanic Gardens, pp. 3-15, Córdoba, España. Koenigstein: Koeltz Scientific Books.

CLEMENTE, M., P. CONTRERAS, J. SUSIN \& F. PLIEGO ALFARO - 1991- Micropropagation of Artemisia granatensis Boiss. Hortscience 26: 420.

CHEE, P.P. -1995- Stimulation of adventitious rooting of Taxus species by thiamine. Plant Cell Rep. 14: 753-757.

FAY, M.F. -1992- Conservation of rare and endangered plants using in vitro methods. J. In Vitro Cell Develop. Biol.- Plant 28: 1-4.

HUSSEY, G. -1986-Vegetative propagation of plant by tissue culture. En: M.M. Yeoman (ed.), Plant Cell Culture Technology, Botanical Monograph vol. 23. pp. 29-66. Blackwell Scientific Publications, Gran Bretaña.

MURASHIGE, T. \& F. SKOOG -1962- A revised medium for rapid growth and bio-assays with tobacco tissue cultures. Physiol. Plant. 15: 473497.

PENNELL, D. -1987-Micropropagation in Horticulture. Grower Books, Londres.

PHILLIPS, J.M. \& D.S. HAYMAN - 1970- Improved procedures for clearing roots and staining parasitic and vesicular-arbuscular mycorrhizal fungi for rapid assessment of infection. Transactions of the British Mycological Society 55: 158-161.

RIVAS MARTÍNEZ, S -1974- Echinospartum lusitanicum (L.) Rothm., amplo sensu. Bol. R. Soc. Española Hist. Nat. (Biol.) 72 :13-18.

SCOTT, M.A. -1986- Weaning of Cultured Plants. En: P.G. Alderson y W.M. Dullforce (eds), Micropropagation in Horticulture: Practice and Commercial Problems. Proceedings of the Inst. of Horticulture Symposium, pp. 173-182. Universidad de Nottingham School of Agriculture.
STAFFORD, A. -1991- Genetics of Cultured Plant Cells. En: A. Stafford y G. Warren (eds.), Plant Cell and Tissue Culture, pp. 25-46. Open University Press, Gran Bretaña.

TALAVERA, S y A. APARICIO - 1995- Una nueva especie del género Echinospartum (Spach) Rothm. Acta Bot. Malacitana 20: 295-298.

TREMBLAY, F.M., P. PÉRINET \& M. LALINDE 1986- Tissue culture of Alnus spp. with regard to symbioses. En: Y.P.S. Bajaj (ed.), Biotechnology in Agriculture and Forestry 1, pp. 87-100, Springer-Berlag, Berlín, Alemania.

YEOMAN, M.M. -1986- Plant Cell Culture Technology. Botanical Monographs Vol. 23.. M.M. Yeoman (ed). Blackwell Scientific, Gran Bretaña.

ZÁRATE, R., M. CANTOS \& A. TRONCOSO 1997- Induction and development of adventitious shoots of Atropa baetica as a means of propagation. Euphytica 94: 361-366.

Aceptado para su publicación en Agosto de 1997

Dirección de los autores. R. Zárate, M. Cantos y A. Troncoso: Instituto de Recursos Naturales y Agrobiología de Sevilla (IRNAS), CSIC, Apdo. 1052, 41080 Sevilla. A. Aparicio: Departamento de Biología Vegetal y Ecología, Facultad de Farmacia, Universidad de Sevilla, C/ Prof. García González s/ n 41012, Sevilla. 